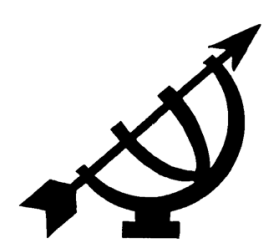

\title{
Die ontwerp van 'n kategesekurrikulum vir graad 1-3 in die Gereformeerde Kerke in Suid-Afrika
}

\author{
J.M. Dreyer \\ Onderwysersopleiding \\ Unisa \\ PRETORIA \\ E-pos: dreyejm1@unisa.ac.za \\ F.P. Kruger \\ Skool vir Kerkwetenskappe \\ Potchefstroomkampus \\ Noordwes-Universiteit \\ POTCHEFSTROOM \\ E-pos: ferdikruger@mweb.co.za
}

\section{Abstract \\ Designing a catechesis curriculum for Grades 1-3 in the Reformed Churches in South Africa}

This article describes the methodological approach that was used in the design of a curriculum for children in Grades 1-3 in the Reformed Churches in South Africa. The curriculum structure must guide the children to form an impression of and come to a realisation about the greatness of the Word of God. Catechism is a resolute instruction with a very specific learning outcome. In a society with postmodern thinking a catechism demands a lot from religious instructors. Various fundamental principles are no longer considered as self-evident. The contemporary endeavour to reach children in a purposeful manner has been an enterprise of the church throughout its history. Identifying the shortcomings of the past can guide us towards building on firm principles in future. 


\section{Opsomming}

\section{Die ontwerp van 'n kategesekurrikulum vir graad 1-3 in die Gereformeerde Kerke in Suid-Afrika}

Die artikel bied ' $n$ beskrywing van die metodologiese benadering wat in die ontwerp van 'n kurrikulum vir graad 1-3 katkisante in die Gereformeerde Kerke in Suid-Afrika gevolg is. Die kurrikulumstruktuur moet die katkisante begelei om onder die indruk van die grootheid van die Woord van God te kom. Kategese is doelgerigte onderrig met 'n definitiewe leeruitkoms. In 'n postmoderne denkklimaat stel dit egter hoë eise aan kategete, omdat baie aangeleenthede wat vantevore as vanselfsprekend aanvaar is, nie meer sodanig geag word nie. Die hedendaagse strewe om kinders doelgerig te bereik, is in werklikheid 'n strewe van die kerk dwarsdeur die geskiedenis. Identifisering van die gebreke van die verlede kan ons in staat stel om hieruit te leer sodat daar op goeie beginsels voortgebou kan word.

\section{Inleiding}

In die 21e eeu leef kinders in 'n konteks waar hulle lewenskwaliteit bedreig word (Grobbelaar \& Hendriks, 2006:2). Kinders word in 'n era groot waarin hulle met inligting uit alle oorde gebombardeer word. Mense raak gevolglik toenemend inligtinggeoriënteerd. Saam met hierdie bewustheid van inligting, val die klem ook toenemend op wêreldnetwerke waardeur gekommunikeer word (Grobbelaar \& Hendriks, 2006:3-6; Prins, 2000:87-89). Verskillende wêreldnetwerke oefen 'n invloed uit op mense en hulle kinders (Grobbelaar \& Hendriks, 2006:10-12; Castells, 2001:18). Gevolge wat hieruit voortspruit, sluit die volgende in:

- Kinders word in 'n samelewing groot waarin daar 'n identiteitsverlies intree. Die sogenaamde hoofstroomkerke en die tradisionele gesin is besig om hierdeur hulle invloed te verloor. Mense is besig om self 'n nuwe identiteit te probeer skep. Die gevolg is dat baie mense in opstand kom teen die invloed van al die persone en instansies wat voorheen gesag uitgeoefen het.

- Die tradisionele gesin ervaar ook dat die patriargale stelsel waarin die vader die hoof was, begin wankel. In die beroepswêreld gebeur dit al hoe meer dat vroue op gelyke voet met mans begin meeding. Werksgeleenthede vir mans word al skaarser. Hierdie tendense beïnvloed die tradisionele gesinslewe.

- Mense is toenemend op soek na alternatiewe familievorms in die plek van die tradisionele kerngesinsmodel. Enkelhuishoudings is 
tans in ontwikkelende lande aan die toeneem. In Suid-Afrika het kerngesinne vanaf 2002 tot 2007 met ongeveer 17,3\% afgeneem (South African Institute of Race Relations, 2009). Volgens dieselfde Instituut se jongste navorsing woon slegs drie uit elke tien kinders in huisgesinne waar albei ouers teenwoordig is. Die huwelikskoers, met ander woorde die aantal mense wat in die huwelik belangstel, is besig om drasties af te neem. In 1996 het 362 uit 100000 mense in die huwelik getree. Onlangse navorsing toon aan dat 320 uit 100000 mense tans in die huwelik tree (vgl. ook Castells, 2004:218-224; StatsSa, 2005:4).

Uit bogenoemde blyk dat kinders toenemend aan alternatiewe huishoudings blootgestel word en dat veral jonger kinders die trauma van die egskeiding van hulle ouers moet leer verwerk. In baie ander kerngesinne moet die gesinne aanpassings maak, omdat die gesinstruktuur baie kompleks geword het. Statistiek toon aan dat $42 \%$ van die moeders tussen vyftien en 65 jaar wêreldwyd ekonomies aktief is (UNICEF, 2006:12). Die bybelse model van gesag in die ouerhuis en die opdrag van verbondsonderrig word deur al bogenoemde faktore geraak. Die vraag waarmee die kerk vandag gekonfronteer word, is hoe die kind binne 'n postmoderne kultuur bedien moet word. In die kategese word dikwels steeds aanvaar dat die gesag in die ouerhuis gehandhaaf word en dat verbondsonderrig daar plaasvind. Die uitdaging aan kerke in 'n postmoderne wêreld is daarom om kinders (wat nie noodwendig op skool of tuis in die Bybel onderrig word nie), sodanig te begelei dat hulle volgelinge van die Here sal word. Die uitdaging aan die kategese is dus om dit wat aan kinders geleer word by praktiese lewensoefening en lewenspraktyk uit te bring (Nel, 2003:152-154). Die ouerhuis is een van die kernboustene in verbondsonderrig. Kategese is ' $n$ verbesondering van die onderig wat hier geskied.

Strommen en Hardel (2000:1-7) het met die oorgang na die nuwe millennium 'n bepaalde wêreldwye verandering geïdentifiseer. Volgens hierdie outeurs is die tradisie van "passing on the faith in the home" vinnig besig om te verdwyn. Burger (1995:13-20) verwys in sy beskrywing van die kerk in Suid-Afrika na kerke wat in transito verkeer. Sweet (2007:20) koppel 'n identiteit, naamlik die tsoenami van die Postmodernisme, aan die verandering in Suid-Afrika. Teen die agtergrond van die Postmodernisme word grondige vrae gestel oor die rol en plek van opvoeding, sowel as van kategese. Le Roux en Rossouw (1992:537) het heelwat vroeër al besin oor die vraag: Wie moet wat aan die volgende geslag oordra? Hierdie vraag kom neer op 'n ondersoek na dit wat aan kinders geleer word. Nel 
(1987:3) spreek sy kommer daaroor uit dat kinders tradisioneel in die kerk as verlengstukke van ouers beskou is. Daarom pleit hy vir 'n bediening waarin kinders optimaal in die volle lewe en diens van die kerk geïntegreer word. Heystek (1987:15-17) sluit hierby aan en bepleit die erns van modellering in die kategetiese onderrig.

Dit is teen hierdie agtergrond dat die navorsing oor 'n nuwe kurrikulumontwerp vir kategese in die Gereformeerde Kerke in SuidAfrika (GKSA) op beskrywende wyse onderneem is. Die resultate van die navorsing word in hierdie artikel aangebied. In die eerste plek word die beginselraamwerk waaruit gewerk word, geskets; tweedens word 'n historiese oorsig rakende kategese in die GKSA aangebied; daarna volg 'n bespreking van die navorsingsbenadering waarbinne die kurrikulumontwerp ontwikkel is. Laastens word die ontwerp van die katkisasieleerprogramme en -lesse beskryf.

\section{Bybelse beginsels vir die ontwerp van die kategesehandleidings}

Die volgende bybelse beginsels word voorgestel om die beginselraamwerk vir die ontwerp van kategesehandleidings te vorm.

\subsection{Psalm 78:3-10}

In Psalm 78 spreek die digter die gedagte uit dat dit wat aan ouers oor God se Woord geleer en vertel is, nie iets is wat hulle (die ouers) mag verswyg nie. Ouers mag nie die Goeie Nuus vir hulle kinders verberg nie. Die vertelling aan hulle kinders het die roemryke dade van die Here as inhoud. Ouers het die voorreg om die diepte van God se wonders en dade met hulle kinders te deel. Hierdie opdrag uit die Woord is nie 'n opsionele saak nie.

Die doel van hierdie onderrig is volgens Psalm 78:

- sodat ouers kan weet (hoof) wat God in sy Woord sê en dit ook aan hulle kinders kan vertel;

- sodat ouers en kinders hulle vertroue (hart) in die Here kan stel en nie die dade van God vergeet nie; en

- sodat ouers en kinders God se gebooie kan bewaar en in die wet van die Here (hande) kan wandel. 


\subsection{Psalm 116:11}

Die perspektief van hierdie Psalm, naamlik "U leer my hoe om te lewe", lei tot die beginsel dat kategesehandleidings verbondskinders moet begelei om met oorgawe in die geloof te kan lewe. Op grond van die besef dat hoof (rede), hart en hande (optrede) in die kategese betrek moet word, is die doelwit van 'n handleiding om vanuit die Openbaringsgeskiedenis kinders uit die Bybel te begelei. Dit behoort nie net op teoretiese wyse gedoen te word nie, maar ook met ' $n$ duidelike praktiese gerigtheid.

Die voorafgaande kan beskou word as bybelse beginsels vir die ontwerp van 'n kurrikulum vir kategese.

\section{3. 'n Oorsig oor die geskiedenis van kategese}

In die lig van die ondersoekveld is dit noodsaaklik om die ontwerp van 'n kurrikulum binne die GKSA teen 'n breër agtergrond te plaas. Die bondige geskiedkundige agtergrond, wat glad nie op volledigheid aanspraak kan maak nie, behoort enkele grondige vertrekpunte in die ontwerp van die nuwe kurrikulum duideliker te omlyn. Vanuit hierdie oorsig sal dit blyk dat kategese van vroeg af 'n duidelike doelwit gehad het. Oor die fyner indeling van die kategesedoelwit het gelowiges onder verskillende omstandighede en in verskillende tydperke van mekaar verskil. Oor die groter doelwit, naamlik om kinders in hulle geloof te begelei, was daar deurgaans eenstemmigheid. Tydsomstandighede het van vroeg af bepaalde eise aan die kategese gestel soos die postmoderne denke in die huidige tydsgewrig ook doen. Die volgende historiese oorsig poog om enkele historiese merkers vir die noodsaaklikheid van die ontwikkeling van handleidings daar te stel.

\subsection{Kategese in die Vroeë Christelike Kerk}

Die Vroeë Christelike Kerk het 'n sterk missionêre gerigtheid getoon en gelowiges het deur die doop toegang tot die kerk verkry. Mettertyd het die missionêre gerigtheid die weg gebaan vir kategese wat ten doel gehad het om gelowiges wat hulle by die kerk wou voeg, daarvoor voor te berei (Bijlsma, 1972:44-45). In die Vroeë Christelike Kerk is die opkoms van 'n kategumenaat opvallend, maar dit het nie oral presies dieselfde vorm aangeneem nie (Jooste, 1965:16). Aanvanklik was die tydsduur van die kategumenaat nie baie lank nie, maar mettertyd het die tydperk langer geword om sodoende die heidene breedvoeriger te onderrig. Die term catechesis het toe 'n terminus technicus vir kategese geword (Dingemans,1991:168). 
Jooste (1965:17-18) sowel as Bijlsma (1972:47-48) verwys na die middels wat aangewend is om die kategumene (doopleerlinge) mee toe te rus. Dit is opvallend dat die klem nie slegs op teoretiese kennis geval het nie.

- Godsdiensoefeninge gedurende die week en op Sondae was belangrik.

- Van die kategumene is gemeenskap met die gelowiges vereis.

- Ervare gelowiges is as voogde oor die kategumene aangestel.

- 'n Uiteensetting en verduideliking van die doop is gegee.

- 'n Breedvoerige verduideliking van die nagmaal is ook gebied.

- Volgens Bijlsma (1972:47) is gelowiges by wie die gawe van onderrig bestaan het, gebruik om die kerklike onderrig te behartig.

\subsection{Kategese vanaf die vierde eeu}

Drie gebeurtenisse oorheers die volgende era (Jooste, 1965:18):

- Die Edik van Milaan in 313 n.C. - godsdiensvryheid is met hierdie verklaring ingelui.

- In 323 n.C. het keiser Konstantyn die Grote hom doelbewus by die Christelike godsdiens geskaar.

- In 383 n.C. verhef Theodosius die Grote die Christelike godsdiens tot staatsgodsdiens.

Bogenoemde gebeurtenisse bring mee dat mense na die kerk stroom. Die kategumenaat moes in die proses 'n belangrike funksie in die kerk vervul (Jooste, 1965:19). Ongelukkig het 'n grootskaalse vervlakking ingetree omdat mense slegs gedoop en as belydende lidmate van die gemeente toegelaat is.

\subsection{Kategese gedurende die Middeleeue}

In die Middeleeue het die vervlakking in kategese voortgegaan (Dingemans, 1991:170-171). Volgens Bijlsma (1972:52) bestaan daar selfs die nodige getuienis dat die Konsilie van Reims in 625 n.C. besluit het dat diegene wat hulle kinders wou doop slegs die Apostoliese Geloofsbelydenis en die Onse Vader moes kon opsê. Hulle moes verder die onderneming gee dat hulle dit ook aan hulle kinders sou oordra. Lidmaatskap van die kerk was baie belangrik, aangesien die opinie bestaan het dat die kerk die uitdeler van die 
genademiddels is (Jooste, 1965:21). Die doel van kategese is gereduseer tot die kweek van gehoorsame seuns en dogters van die kerk (Bijlsma, 1972:55). Gedurende die dertiende eeu is daar wel in die kerk besef dat groter klem op kategese geplaas behoort te word, maar dit het ongelukkig nie in die praktyk tot sy volle reg gekom nie.

\subsection{Kategese en die Reformasie}

Die Reformasie het die doel van kategese, as die kweek van gehoorsame seuns en dogters, geheel en al verwerp (Jooste, 1965: 22). In die sestiende eeu is die klem opnuut op die inskerping van die Woord van God as kennisbron geplaas (Bijlsma, 1972:61-62; Jooste, 1965:22). Kategese is nie slegs met die doop in verband gebring nie, maar met albei sakramente. Ten tye van die Reformasie is daar met vrug voortgebou op die uitvinding van die boekdrukkuns, asook die demokratisering van die onderwys (Dingemans, 1991:171). Die Bybel is in Latyn en baie ander tale vertaal en sodoende is nuwe moontlikhede vir indringende kategese geskep.

\subsubsection{Martin Luther as kategeet}

Luther (1529) het die noodsaak van kategese opnuut onderstreep deur kategismusse (Die Groot en Klein Kategismus) op te stel en te vereis dat kinders dit uit die kop moes leer (Jooste, 1965:22). Hy het ook gepropageer dat die vordering van die kinders hierin gemoniteer moes word (Bijlsma, 1972:66-69). Ouers het die primêre taak ontvang om hulle kinders te onderrig. Hy het hom voorts daarvoor beywer dat skole gestig moes word waarin die Kategismus onderrig kan word.

\subsubsection{Spener as kategeet}

Onder leiding van Spener (1675) het 'n nuwe bedeling in kategese onderrig aangebreek, aangesien hy die konfirmasie (belydenis van geloof) as eindpunt of leeruitkoms van die kategese beskou het (Jooste, 1965:23). Dit was vir hom belangrik dat, benewens die verstand (onderrig in die leer van die kerk), die gevoel van kinders ook eerbiedig moes word. Die ondersoek/ondervraging voor konfirmasie was nie gemik op 'n ondersoek na kennis nie, maar eerder 'n ondersoek na die vrugte van die bekering (Jooste, 1965:23).

\subsubsection{Johannes Calvyn as kategeet}

Calvyn (Calvin, 1542) het verskeie kategismusse opgestel wat veral in Switserland en Frankryk met vrug gebruik is (Bijlsma, 1972:66-67; Jooste, 1965:24). Calvyn het die klem opnuut op die plig van ouers 
ten opsigte van verbondsonderrig geplaas. In 1541 werk Calvyn mee aan 'n bepaling wat uitgevaardig word en soos volg lui:

Alle inwoners moet hulle kinders Sondagmiddae na die kategese begelei of stuur. As 'n kind genoegsaam onderrig is, moet hy die hoofsaak van die kategismus opsê. Voor die tyd mag hy nie na die nagmaal toe kom nie. Skoolgaande kinders moet om twaalfuur by die skool bymekaarkom om deur die skoolmeesters na die kategese geneem te word, en vir die ander kinders moet die ouers sorg. (Jooste, 1965:24.)

Calvyn het reeds in daardie tyd opgemerk dat 'n vervlakking in kategese meebring dat 'n kerk sy eie kerkvervreemdes kweek.

\subsubsection{Gevolgtrekkings}

Uit bogenoemde oorsig blyk die volgende:

Aanvanklik het kategese die weg gebaan vir gelowiges om deel te word van die Christelike kerk. In die Vroeë Christelike Kerk het kategese 'n duidelike raakvlak met die ander dimensies van kerkwees openbaar. Vanaf die vierde eeu n.C. tree vervlakking egter in die kategese in en bring daarmee die gevaar van 'n Christendom wat slegs in naam bestaan. Tydens die Middeleeue is die klem op kerklidmaatskap as sodanig geplaas, sodat kategese min aandag ontvang het. Die Reformasie het egter die belangrikheid van kategese as kerklike onderrig opnuut onderstreep.

\section{4. 'n Kort oorsig oor kategese in die GKSA sedert 1859}

In die tydperk 1652-1858 is daar in die kategese in Suid-Afrika aangesluit by die situasie in Nederland rondom die Dordtse Sinode (Van der Merwe, 2009:35). Van der Merwe (2009:35) toon aan dat die leeruitkoms van kategese was om kinders tot die vaste grond van geloof en sodoende tot 'n godvresende lewenswandel te bring.

$\mathrm{Nel}(1986: 85)$ sluit hierby aan en benadruk die klem wat in die beginjare geplaas is op huis, skool asook kerklike kategese. In hierdie tydperk was veral die ouers en die skole met kategese gemoeid. Hieruit kan, volgens Nel (1986:86), die afleiding gemaak word dat die skole tydens die beginjare in die Kaap in diens van die kerk gestaan het. Teen die einde van die agtiende eeu was die onderskeid tussen kerk en skool groter. Daar is veral drie brandpunte in die kategese-onderrig onderskei, naamlik bybelse geskiedenis, geloofsleer en kerkgeskiedenis. 
Op 10-11 Februarie 1859 kom die Gereformeerde Kerke in SuidAfrika (GKSA) tot stand. In hierdie onderafdeling word 'n oorsig gebied van die kategesegeskiedenis in die Gereformeerde Kerke in Suid-Afrika sedert 1859. Hierdie artikel is nie primêr 'n artikel wat oor die geskiedenis handel nie en daarom sal slegs 'n bondige oorsig gebied word wat moontlik as verduideliking kan dien vir die rede waarom 'n nuwe kurrikulum ontwikkel moet word.

$\mathrm{Na}$ die totstandkoming van die nuwe kerk, die GKSA, het die klem noodgedwonge op 'n besinning oor die opvoeding en bediening van die jeug geval. Kategese en onderwys het besinning voortgebring (De Wet \& Coetzee, 1943:90). Die opvoeding van kinders tuis en op skool moes hande vat. Baie klem is op gereformeerde kerkskole geplaas, omdat die plaaslike kerkraad daaroor moes toesig hou (De Wet \& Coetzee, 1943:93). Die kerkskole het 'n belangrike rol gespeel, aangesien gereelde kategese veral op die platteland nie altyd haalbaar was nie. In 1873 word besluit dat die Kort Begrip en die Heidelbergse Kategismus die leerstof/kurrikulum van die kategese sou uitmaak. Aanvanklik is daar baie geworstel oor die ouderdom waarop katkisante belydenis van geloof moes aflê. In 1876 het die sinode beklemtoon dat kerkrade hierdie saak met groot omsigtigheid moes benader (De Wet \& Coetzee, 1943:100). Lesroosters is uitgewerk waarvolgens katkisante moes voorberei. De Wet en Coetzee (1943:102) bied in hulle navorsing 'n voorbeeld van so 'n lesrooster:

\begin{tabular}{|l|l|l|l|l|}
\hline Datum & Psalmvers & Borstius & Kort begrip & Bybel \\
\hline 2 Jan & $39: 4$ & p. 5 & $43-45$ vrae & Lot en Sodom \\
\hline 9 Jan & $26: 4$ & p. 6 & $46-47$ vrae & Abraham \\
\hline 16 Jan & $27: 4$ & p. 6 & $48-51$ vrae & Isak en Esau \\
\hline 23 Jan & $28: 4$ & p. 7 & $52-56$ vrae & Jakob \\
\hline 30 Jan & $29: 4$ & p. 7 & $57-60$ vrae & Jakob se seuns \\
\hline
\end{tabular}

Benewens bogenoemde lesrooster is daar ook 'n Bybelhoofstuk by die rooster gevoeg. Vanaf 1899-1908 het georganiseerde kategese vanweë die oorlog tot stilstand gekom. In 1904 gebeur daar egter iets wat van groot belang is vir die kategese van kleiner kindertjies. Daar is besluit dat kerkrade meer moeite moet doen om, benewens die ander kategetiese stof, die Bybelverhale aan jonger kinders te vertel (De Wet \& Coetzee, 1943:104).

Vanaf 1909 tot 1925 ontstaan daar 'n nuwe belangstelling in kategese. Drie sake oorheers die toneel, naamlik lesroosters, leerboe- 
kies en die kwessie van onderrig. In die jare daarna sou die leerboeke gedurig onder skoot kom (De Wet \& Coetzee, 1943:112-113). In die tydperk 1925-1940 staan die ontwikkeling van handboeke op die voorgrond. Die bevatlikheid van die lesmateriaal geniet in hierdie jare prominente aandag. Vier ouderdomsgroepe word onderskei, naamlik 6-9 jaar, 10-12 jaar, 13-16 jaar en ouer as 16 jaar (De Wet \& Coetzee, 1943:114).

Die tydperk 1940-1958 word deur 'n wisselwerking tussen opvoedkunde en kategese gekenmerk (Spoelstra, s.a.:38). Die klem word ook toenemend op sentralisasie geplaas, met ander woorde bepaalde deputate vir kategese is verantwoordelik daarvoor om lesmateriaal op te stel. Die behoefte begin ontstaan om eenvormige kategesemateriaal vir die kerkverband daar te stel. In hierdie tydperk word die oordrag van kennis beklemtoon (Spoelstra, s.a.:40). Die klem rus veral daarop dat kategese die amptelike verkondiging van die Woord aan verbondskinders is. Daar word verder nadruk geplaas op die feit dat kategese nie moet verval in die opsê van 'n les of in die beantwoord van vrae nie. Verder word herhaling en die toeëiening van lesmateriaal ook toenemend benadruk. Gedurende die tydperk 1959 tot 1988 vind 'n prinsipiële uitbouing van kategese plaas. Die Nasionale Sinodes van 1964 en 1967 het toenemend benadruk dat die leeruitkoms van kategese moet wees om kinders tot 'n persoonlike geloofsbelydenis te bring (Van der Merwe, 2009:35).

Die behoefte aan 'n eenvormige kategesesillabus kom in hierdie tyd aan die lig (Spoelstra, s.a.:45). In 1976 word 'n sillabus volgens die skoolstanderds daargestel (GKSA, 1976:557). In die tydperk 19801982 word die uitdrukking/frase handleiding om kinders in die Bybel te begelei in plaas van ' $n$ handboek by die Bybel, toenemend op die voorgrond geplaas. Dit is 'n waterskeiding in die denke van die Gereformeerde Kerke in Suid-Afrika. In hierdie tyd val die klem toenemend op die onderrig van die Woord tot geloofsekerheid wat in die lewenswandel sigbaar moet word (Van der Merwe, 2009:36).

\subsection{Gevolgtrekkings}

Aanvanklik het die Gereformeerde Kerke in Suid-Afrika in handboeke na lesmateriaal gesoek. Met verloop van tyd is besef dat handboeke katkisante onnodig van die Bybel verwyder. Kategese moet kinders begelei om die Bybel te kan hanteer. Die gebruik van die term handleiding eerder as handboek het in die geskiedkundige oorsig deurgaans na vore gekom. 'n Handleiding begelei kinders tot kennis van die Bybel, asook die doelbewuste navolging van hierdie 
waarhede. Binne die GKSA het daar volgens die historiese kontoere 'n duidelike behoefte ontstaan aan 'n eenvormige kurrikulum waarmee verbondskinders begelei kan word. Die kategesehandleidings van 1982-2010 is gevolglik daarop ingestel om katkisante aan die hand van Bybelgedeeltes in die Skrif in te lei.

\section{Kurrikulumontwerp van katkisasieleerprogramme}

Die bespreking van die kurrikulumontwerp word hier beperk tot die katkisasieleerprogramme vir graad 1-3.

\subsection{Kurrikulumontwikkeling}

Carl et al. (1988:23) dui aan dat kurrikulumontwikkeling uit 'n aantal fases bestaan, naamlik kurrikulumontwerp, -disseminasie, -implementering en -evaluasie.

\subsection{Kurrikulumontwerp}

In 'n ondersoek na 'n aantal bestaande Suid-Afrikaanse modelle wat vir die ontwerp van 'n kurrikulum ontwikkel is, het Carl (1995:94) sekere gemeenskaplike faktore gevind, naamlik situasie-analise, formulering van doelstellings en doelwitte, die keuse en klassifikasie van inhoude, die keuse van metodes, tegnieke en media, die keuse en klassifikasie van leerervarings, die beplanning en implementering van onderrigleersituasies en die evaluering van leerlinge. Al hierdie elemente van kurrikulumontwerp word in ag geneem en kan in hierdie artikel gevind word.

\subsection{Die noodsaak van 'n nuwe kurrikulumontwerp en katkisasieleerprogramme vir graad 1-3}

Die noodsaak vir 'n nuwe kurrikulumontwerp en nuwe handleidings het om verskeie redes na vore getree. Sedert 1982 het verskeie deputategroepe hulle daarvoor beywer om in die lig van die behoeftes van katkisante handleidings daar te stel wat aan die behoefte voldoen. Vanaf 1982-1999 het twee reekse verskyn:

- Ken en vertrou in 1982 (meer kennisgerig).

- Ken, vertrou en doen in 1999 (met klem op praktiese uitlewing).

Die klem in die handleidings is algaande meer op ouerbetrokkenheid asook op die praktiese uitlewing van die lesmateriaal geplaas. Die handleidings onderskei vier fokusareas: 
- Openbaringsgeskiedenis

- Belydenis

- Koninkryk

- Kerk

In 2006 ontvang die katkisasiedeputate opdrag om die bestaande handleidings te hersien in die lig van behoeftes by die gemeentes en katkisante, kommentaar uit die gemeentes en volgehoue studie oor die beste metodes vir katkisasie-onderrig (GKSA, 2006:370). Vanuit die GKSA-kerkverband is toenemend kommentaar gelewer oor

- die fragmentariese wyse waarop die ouerhandleidings die Woord laat spreek;

- die organiese openbaringshistoriese lyn wat nie in die handleidings verreken word nie;

- die begripsvermoë van kinders wat nie volledig in berekening gebring is nie; en

- die konkrete onderwysbedeling in 'n nuwe politieke bedeling waarin godsdiensonderrig toenemend aan die verdwyn was.

Die katkisasiedeputate het besluit om die hersiening te begin met die ontwerp van 'n nuwe kurrikulum en leerprogramme vir graad 1-3. Die doelstellings was om 'n kurrikulum te ontwerp en handleidings te ontwikkel wat

- gepaste leerinhoude vir katkisante vir graad 1-3 bevat wat sal verseker dat hulle die Here uit sy Woord leer ken;

- katkisante help om Bybelkennis met lewenskwessies en uitdagings wat op hulle lewens betrekking het, in verband te bring;

- geskik is vir die bevatlikheidsvlak van graad 1-3-katkisante;

- ouerbetrokkenheid bevorder;

- leiding bied aan kategete oor wat aangebied moet word;

- leiding bied aan kategete oor hoe om katkisasie aan te bied; en

- aktiewe leer aanmoedig. 


\section{Navorsingsbenadering en -metodologie}

Kategese veronderstel ' $n$ baie spesifieke manier van leer met baie spesifieke inhoude, vaardighede en waardes. Die 2006-katkisasiedeputate moes dus ' $n$ geskikte navorsingsbenadering en navorsingsmetodes vind om 'n doelmatige kurrikulum te ontwerp en handleidings te ontwikkel om sodanige leer te verseker.

\subsection{Navorsingsbenadering}

Die navorsing rakende die kurrikulumontwerp van katkisasie-leerprogramme is vanuit die raamwerk van die gesitueerde leer-, kulturele mediasie- en begeleide leerteorieë onderneem. Dit bied insig in die keuse van die onderrig- en leerbenadering wat meestal by katkisasie in die GKSA gebruik word.

In hulle baanbrekerswerk dui Lave en Wenger (1991:110) aan dat gesitueerde leer deur, wat hulle noem, 'n gemeenskapspraktyk ('n geloofsgemeenskap in die konteks van hierdie artikel) gekenmerk word. Hiervolgens sal die nuweling (dooplidmaat) die werking of funksionering van die gemeenskap aanvanklik net van die buiterand af waarneem - sogenaamde "aanvaarbare periferale deelname" waarna mettertyd groter deelname ontwikkel. Toegepas op kategese, behels dit dat katkisante stelselmatig tot die nodige insig groei, waarna hulle hul geloof bely en ook die voorneme uitspreek om as meelewende of funksionele lede van die gemeente te funksioneer.

Tydens bogenoemde proses word die leerder gehelp om die kultuur van die gemeenskap te verstaan en te assimileer (Clancey, 1995: 55). Vanuit 'n katkisasieperspektief beteken dit dat die volle gemeenskap van die kerk vir leerders ontsluit word deur toegang tot aktiwiteite van die geloofsgemeenskap soos Woordbediening, sakramentbediening en die aanwending van hulle gawes tot nut van ander gelowiges.

Daar word met ander woorde vereis dat iemand eers leer hoe om 'n lid van die gemeenskap te wees, omdat hy/sy kennis benodig om met hart en daad toegewyd as lid te kan funksioneer. Om dit te verwesenlik, word spesiale werktuie soos boeke gebruik om die interaksie met die gemeenskap tydens die leerproses te fasiliteer (Clancey, 1995:55).

Om dit in konteks te plaas: hierdie artikel konsentreer op die kennis, vaardighede en waardes (die katkisasiekurrikuluminhoude) wat deur katkisante benodig word om as funksionele gelowiges in die Gere- 
formeerde Kerke (maar ook in die koninkryk waar Christus nagevolg word) te groei. Die katkisasiehandleidings wat volgens hierdie kurrikulum saamgestel word, is een van die werktuie wat gebruik word om die leer wat moet plaasvind, te fasiliteer.

Die tweede leerteorie wat vir hierdie studie van betekenis is, het te maak met hoe leer plaasvind (spesifiek tydens katkisasie). Dit is op Vygotsky (1978) se teorie van kulturele mediasie gebaseer, waarvolgens kinders deur interaksie met betekenisvolle mense in sy/haar lewe leer (in hierdie geval ouers en kategete). Kinders kan deur hierdie interaksies die gewoontes en sienswyses van hulle kultuurgemeenskap leer ken en internaliseer (Vygotsky \& Luria, 1993).

Dit sluit aan by die derde leerteorie relevant tot die studie, naamlik die begeleide leerteorie van Feuerstein (1980; 1990), wat verduidelik hoe leer in die leersituasie (tydens katkisasie) gemedieer word. Volgens Feuerstein en Feuerstein (1991:26), word die kind aan twee tipes leersituasies blootgestel, naamlik direkte leer (wat tussen die kind en die leermateriaal plaasvind), en begeleide leer (waar leer gemedieer of bemiddel word deur 'n reeds-geïnisieerde volwassene wat die kind doelbewus begelei om bepaalde inhoude en vaardighede aan te leer). Begeleide leer (in hierdie geval ouer- en kategeetbegeleide leer) is die voorkeurmetode om die leer wat in katkisasie vereis word, te medieer.

In die praktyk bepaal die geloofsgemeenskap (die GKSA) dus wat geleer moet word of wat die kurrikuluminhoude (uiteraard uit die Bybel afgelei) behels. Katkisant-, ouer- en kategeet-handleidings (werktuie of onderrig- en leermateriaal) word aan die hand van hierdie kurrikuluminhoude ontwikkel. Hiermee kan leer gemedieer word en word ouer- en kategeetbegeleide leer (as leermetode) moontlik gemaak. Vanuit hierdie rasionaal vind die kurrikulumontwerp vir kategese plaas.

\subsection{Navorsingsmetodologie}

In die navorsing wat met die ontwerp van 'n nuwe kurrikulum vir graad 1-3-katkisante verband hou, is van kwantitatiewe en kwalitatiewe navorsingsmetodes gebruikgemaak vir dataversameling. Dit is ' $n$ sogenaamde gemengde metodologiese benadering, soos beskryf deur McMillan en Schumacher (2006:400-406). Kwantitatiewe data is deur die gebruik van vraelyste, kwalitatiewe data uit kommentaar, insette vanuit gemeentes en uit fokusgroeponderhoude verkry. 
Die onderhawige studie is 'n beskrywende en verduidelikende studie waarin die kurrikulumontwerp en gepaardgaande ontwerp van katkisasiehandleidings beskryf en verduidelik word. Omdat die fokus van die studie op een organisasie (die GKSA) val, is dit inherent ook 'n gevallestudie. Verder is dit 'n enkelvoudige gevallestudie (McMillan \& Schumacher, 2006:317) aangesien dit tot een groep (die GKSA) beperk is - 'n groep wat deur 'n sosiaal-kulturele grens afgebaken word. In 'n sekere sin is die studie ook emansiperend (Marshall \& Rossman, 1999:33), aangesien daar ondersoek ingestel word na hoe die groep (die GKSA) 'n probleem (die ontwerp van 'n geskikte kurrikulum en lesmateriaal) ervaar en dan positiewe aksie neem om dit te hanteer.

\subsection{Dataversameling}

Data is op 'n verskeidenheid maniere versamel.

\subsubsection{Verkennende dataversameling (situasie-analise)}

Alle gemeentes van die GKSA (389 gemeentes) is genooi om op die bestaande handleidings kommentaar te lewer. Insette is van twintig gemeentes ontvang. Geen begeleiding met betrekking tot die formaat van kommentaarlewering is gegee nie. Daar is bloot per brief aan gemeentes vir kommentaar en voorstelle gevra. Insette is ook verkry van kategete en hulpkategete wat opleidingsessies bygewoon het wat deur katkisasiedeputate aangebied is. Die insette wat op hierdie wyse ingesamel is, is by oorwegend stedelike gemeentes in die Pretoria/Tshwane-omgewing, gemeentes aan die Oos-Rand, asook twee gemeentes in Bellville gekry. Verder het gemeentes op 'n ad hoc-basis kommentaar deurgegee. Al die data wat verkry is, was dus ongestruktureerd en moes verwerk word. Dit is gedoen deur die kodering van die data wat in 'n aantal waarneembare kategorieë gemanifesteer het.

Die volgende kategorieë is gebruik:

- formaat van handleidings

- kurrikulumtemas

- bevatlikheidsvlak

- leeraktiwiteite

- leerinhoude

Tipiese opmerkings/kommentaar wat ontvang is, sluit in: 
- Formaat: "Die uitleg, grafika en voorkoms van handleidings is nie professioneel nie."

- Kurrikulumtemas: "Katkisante leer nie genoeg van die bybelse Openbaringsgeskiedenis nie."

- Bevatlikheidsvlak: "Sommige aktiwiteite kan nie gebruik word nie, omdat katkisante nie die vaardighede het om dit te doen nie (bv. al die graad 1-katkisante kan nog nie skryf nie - veral aan die begin van die jaar)."

- Leeraktiwiteite: "Sommige aktiwiteite dra nie tot begrips-vaslegging by nie en is eintlik sinneloos."

- Leerinhoude: "Meer klem moet op Bybelverhale, soos dié van Simson en Gideon, geplaas word."

- Die bevindings is deeglik deur die katkisasiedeputate bestudeer en bespreek. Daar is besluit om verdere navorsing (addisionele situasie-analise) te doen om 'n meer verteenwoordigende siening vanuit die kerkgemeenskap te verkry oor wat die verwagting in verband met die kategeethandleidings is. Hiervoor is ' $n$ vraelys ontwerp en is gemeentes uitgenooi om 'n werkswinkel wat op herkurrikulering sou fokus, by te woon.

\subsection{2 'n Werkswinkel}

Die werkswinkel is deur 28 verteenwoordigers van Gereformeerde Kerke bygewoon. Verteenwoordigers was hoofsaaklik predikante (12) en katkisasie-organiseerders (6), maar ook hulpkategete (8) en 'n jeugwerker (1); afkomstig van stedelike (16), plattelandse (12), groot (11), medium (10) en klein (5) gemeentes vanuit ses provinsies. Agt van die verteenwoordigers was vroulik, terwyl ouderdomme soos volg verteenwoordig was: $20-30$-jariges: drie; 31-40-jariges: twaalf; 41-50-jariges: nege; bo 50 jaar: vier. Tydens die werkswinkel is al die afgevaardigdes versoek om eers die vraelys te voltooi.

Die vraelys is saamgestel met inagneming van die bevindings wat uit die verkennende data verkry is. Vrae rakende al die genoemde kategorieë is doelbewus ingesluit. Die data is verwerk en die volgende is bevind (meer as een respons was by sekere vrae moontlik en die resultate word dus as persentasies aangebied). 


\section{Vraag 1:}

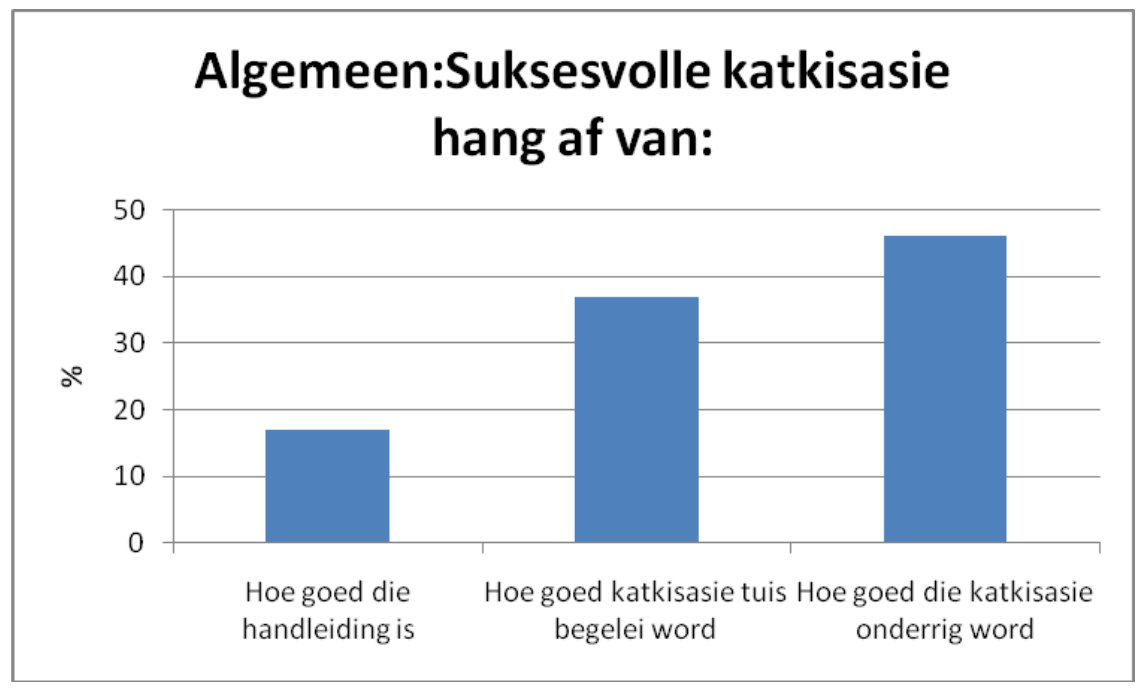

Die meeste respondente is daarvan bewus dat die begeleiers (ouers en kategete) belangriker is as die handleidings self. Dit beteken egter nie dat hulle dink handleidings moet nie opgestel of gebruik word nie; of dat beter handleidings hulle begeleidingstaak sal vergemaklik nie.

\section{Vraag 2:}

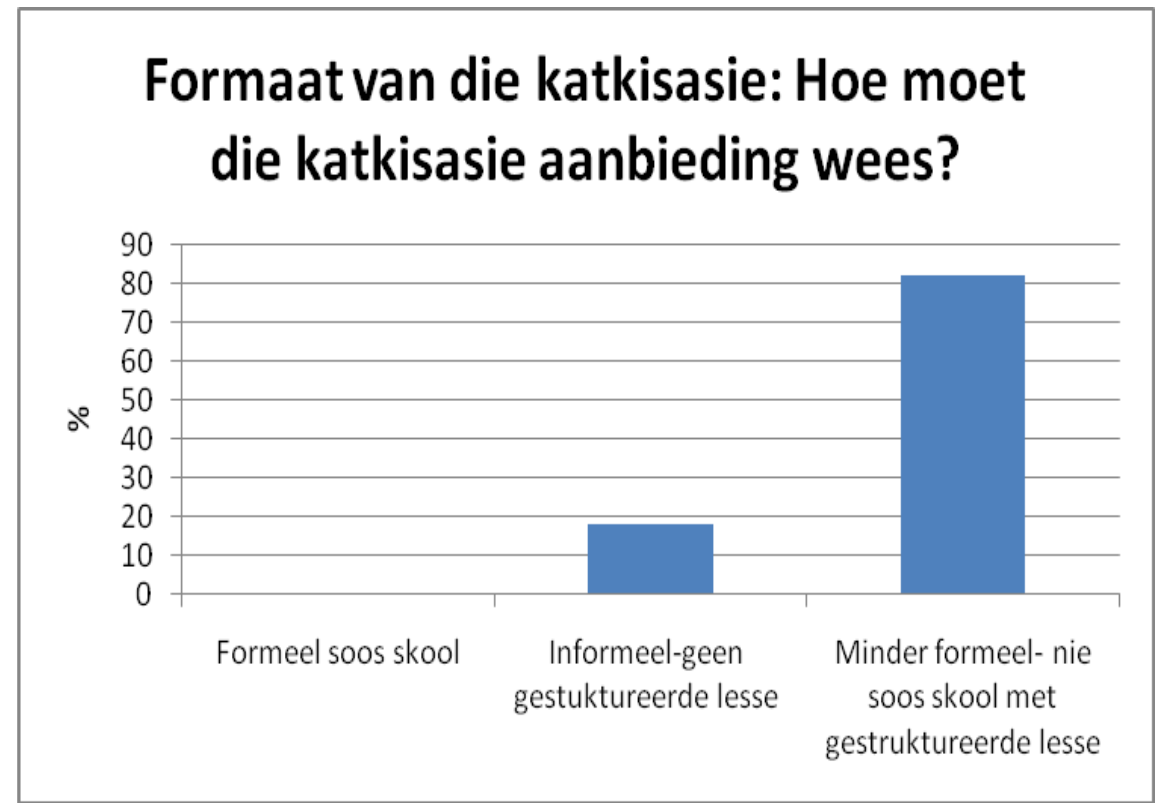

Verreweg die meeste respondente voel dat katkisasie minder formeel as skoolonderrig moet wees, maar dat daar wel gestruktureerde lesplanne vir gebruik tydens katkisasie ontwikkel moet word. 


\section{Vraag 3:}

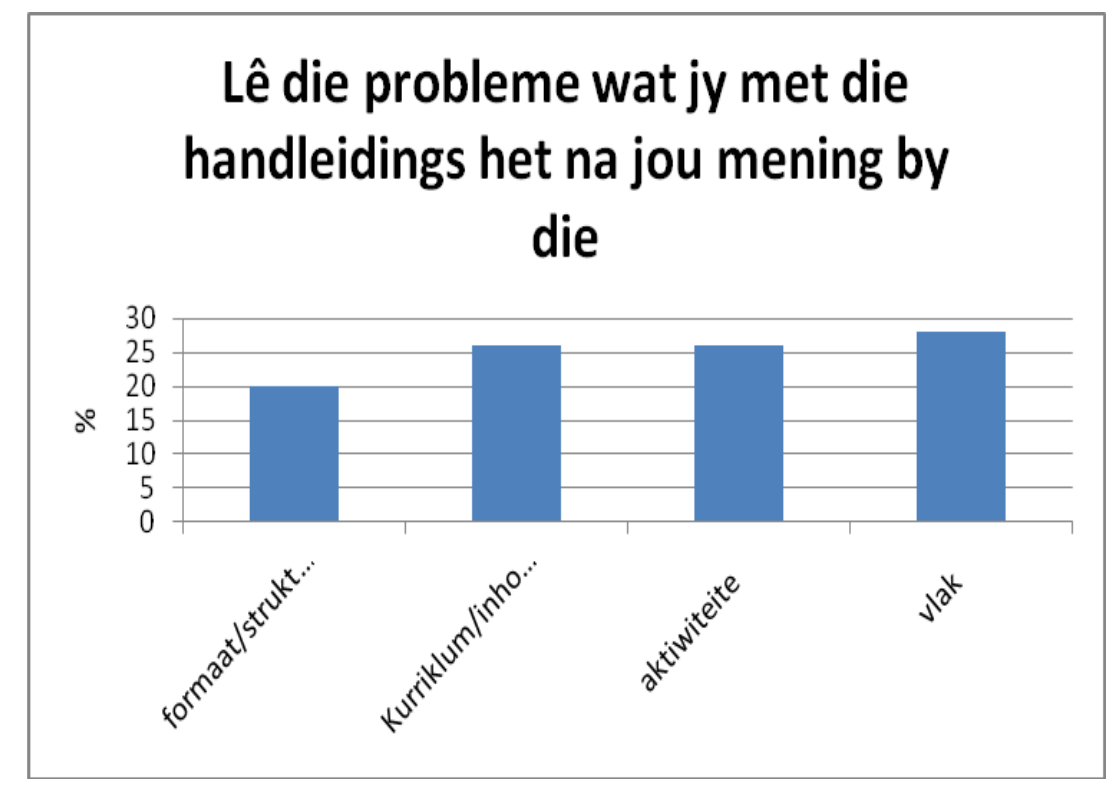

\section{Vraag 4:}

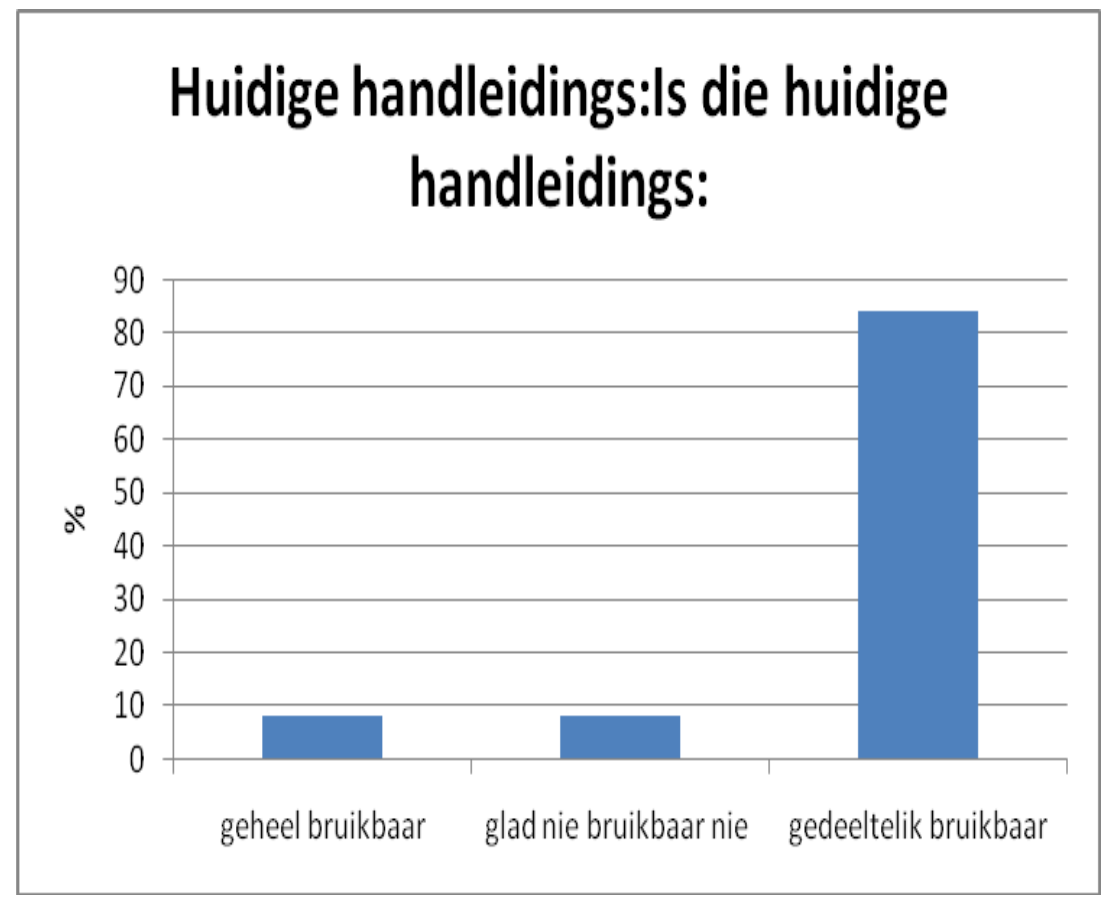

Respondente het gevoel dat die bestaande handleidings wel waarde het, maar dat daar ook heelparty tekortkomings is - tekortkomings soos dié wat reeds hierbo by die verkennende data uitgewys is. Die volgende tekortkomings (in volgorde van die meeste na die minste genoem) is ook onder algemene kommentaar en voorstelle gelys: 
- Die inhoud moet uit Openbaringsgeskiedenis bestaan wat oor drie jaar (gr. 1-3) gedek word.

- Die bladuitleg moet professioneel gedoen word.

- Lesse moet so ver moontlik chronologies volgens die volgorde in die Bybel aangebied word.

\section{Vraag 5:}

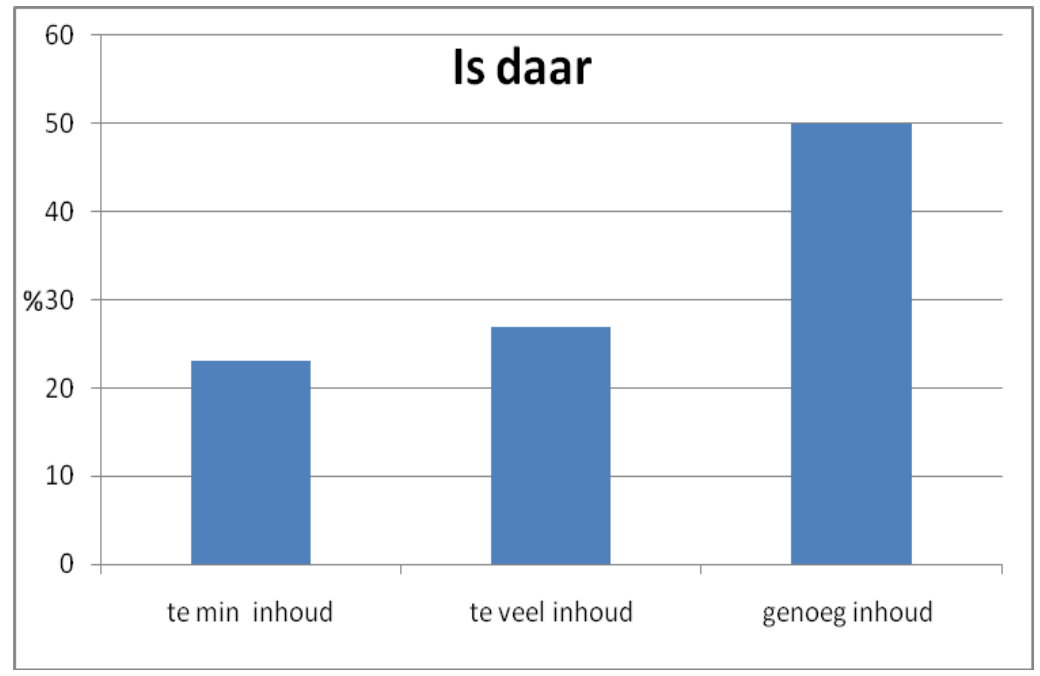

Die probleme wat uitgewys is, dek alle aspekte van die bestaande handleidings. Dit was veral die antwoord op hierdie vraag wat die deputate vir katkisasie genoop het om te besluit om die bestaande handleidings in geheel te herkurrikuleer en van nuuts af te ontwikkel sodat daar aan elkeen van die probleemareas aandag geskenk kon word.

\section{Vraag 6:}

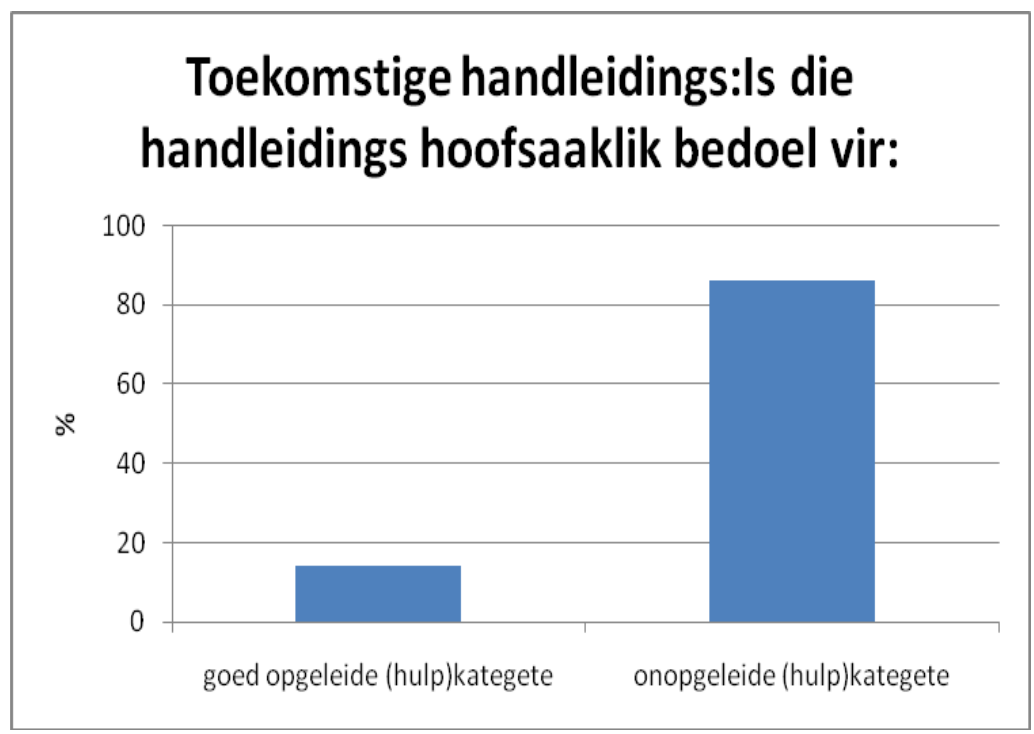




\section{Vraag 7:}

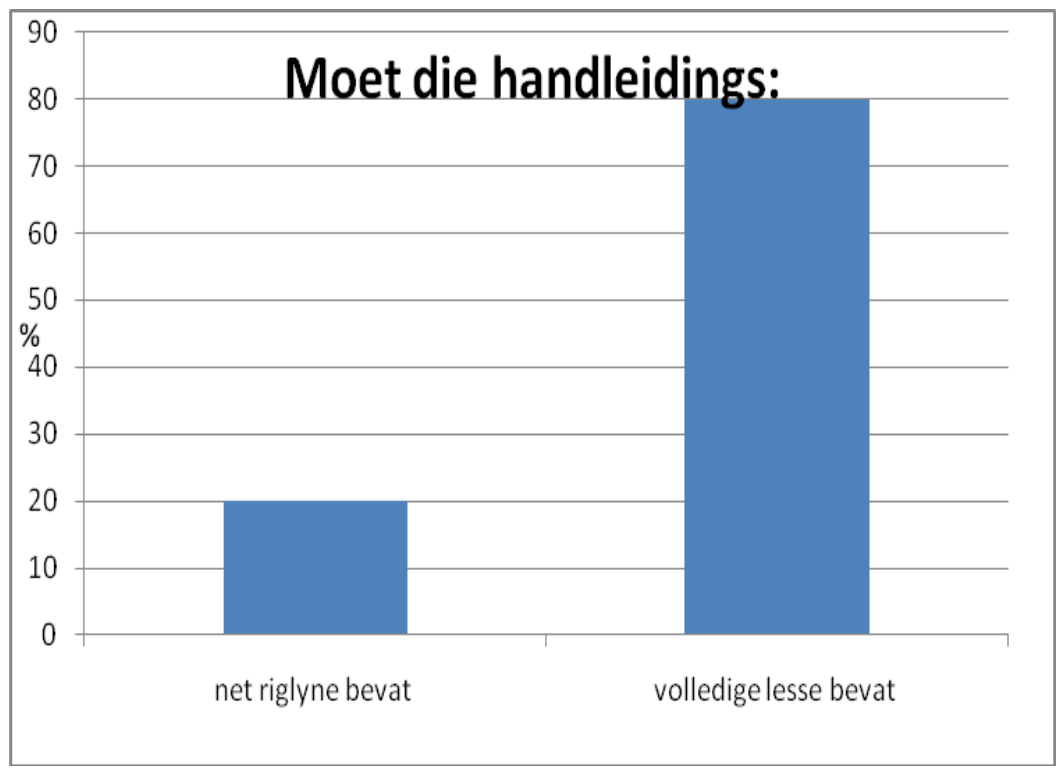

Die nuwe handleidings moes op so 'n wyse saamgestel word dat onopgeleide hulpkategete (lidmate) dit effektief sou kon gebruik. Soos ook by vraag 2 aangedui is, was die meeste respondente dit eens dat volledige lesplanne ontwikkel moes word.

\section{Vraag 8:}

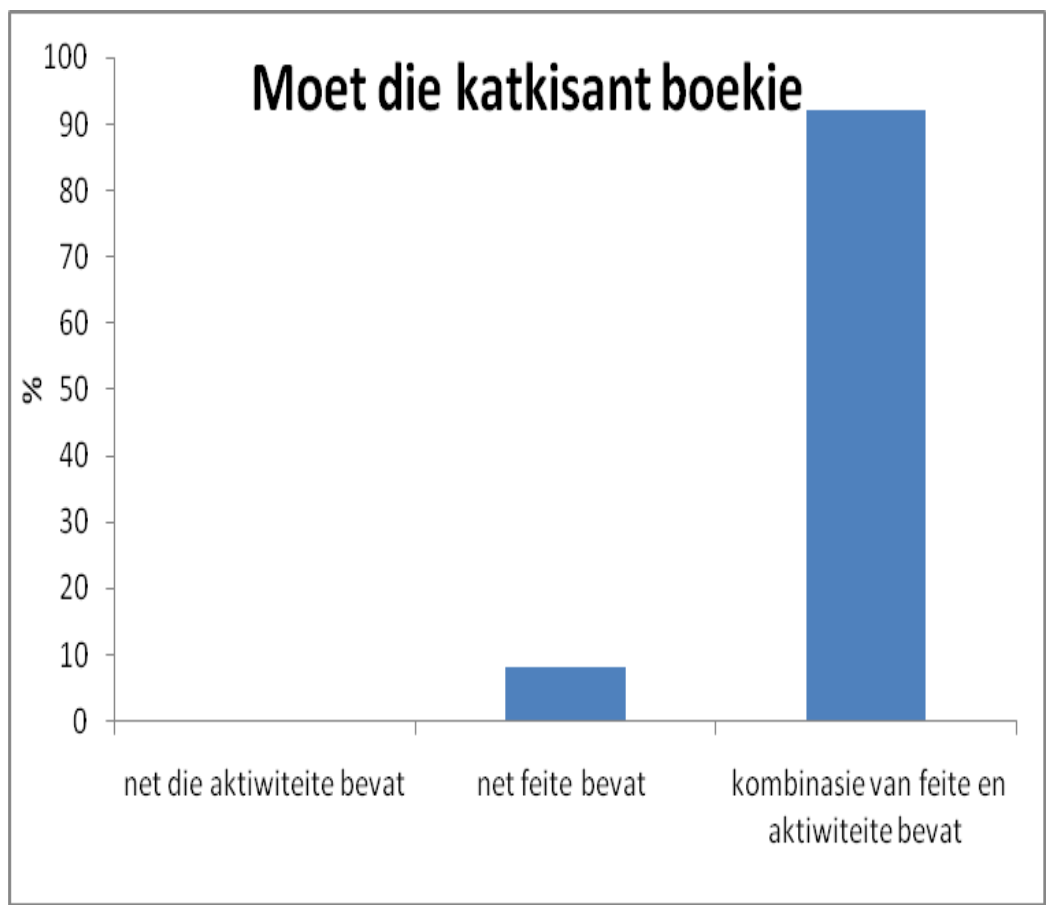

Die oorgrote meerderheid respondente was van mening dat katkisante se werksboekies feite sowel as lesaktiwiteite moet bevat. Respondente is ook die geleentheid gegun om kommentaar te lewer 
of voorstelle te maak ten opsigte van die nuwe katkisasiehandleidings wat hulle graag sou wou hê (voorbeelde is reeds hierbo by vraag 3 gegee).

\section{Vraag 9:}

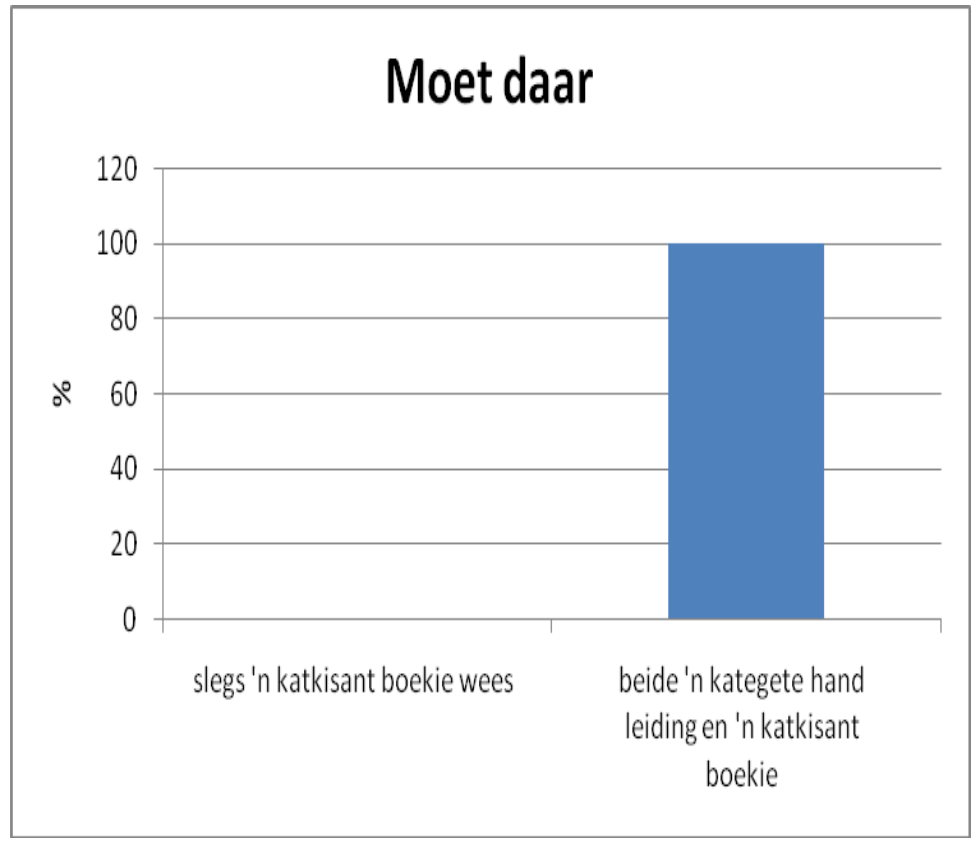

Alle respondente het gevoel dat daar minstens ' $n$ kategetehandleiding en 'n katkisantwerkboekie moet wees. By algemene opmerkings het ' $n$ beduidende aantal respondente aangedui dat daar ook 'n katkisantvoorbereidingsboek, gekombineer met 'n ouerhandleiding moet wees - soos wat met die bestaande handleidings die geval was.

Tendense uit die vraelyste was soortgelyk aan dit wat uit kommentaar en insette van gemeentes verkry is en wat hierbo by die verkennende data aangedui is. Dit het as bevestiging van sodanige bevindings (en dus as ' $n$ vorm van triangulasie) gedien. Die resultate en bevindings is tydens ' $n$ groepsbespreking aan afgevaardigdes voorgehou om groter duidelikheid en meer inhoudryke inligting te verkry. Daar is oor die volgende punte saamgestem:

- Die hersiene kurrikulum moet op die Openbaringsgeskiedenis fokus om Bybelkennis en basiese begrippe by katkisante vas te lê.

- Die Openbaringsgeskiedenis moet oor 'n driejaartydperk (gr. 1-3) gedek word.

- Die aanbieding moet so ver moontlik chronologies wees. 
- Daar moet drie handleidings wees: 'n ouerhandleiding en katkisantvoorbereidingsboek (met die basiese inhoud, Bybelgedeeltes vir voorbereiding en aktiwiteite), 'n katkisantwerkboek (met lesinhoude en -aktiwiteite), en 'n kategeteboek (met addisionele inhoud en idees oor hoe om lesse sinvol aan te bied).

- In die ontwerp van die handleidings is die vereiste gestel dat voorsiening gemaak moet word vir die toerusting van katkisante, met inagneming van die eise van 'n postmoderne samelewing. Dit moet geskied aan die hand van die lestema, die lewenswaarheid en praktykmaking. Die lewenswaarheid dien as praktykgerigte lens waardeur na die tema en openbaringswaarheid gekyk word, terwyl die praktykmaking as toerusting dien om lewensvraagstukke die hoof te bied.

- Die bladuitleg van handleidings moet professioneel gedoen word.

- Die inhoud en aktiwiteite moet op die bevatlikheidsvlak van die betrokke katkisante wees.

- Ervare en kundige opvoedkundiges se hulp moet ingeroep word om die opvoedkundige aspekte van die handleidings te hanteer.

- Die deputate vir katkisasie (predikante) moet die eksegese doen, die fokus van lesse bepaal en dogmatiese akkuraatheid verseker.

\subsubsection{Fokusgroeponderhoude}

Die afgevaardigdes is hierna op grond van hulle kennis, ervaring en belangstelling in drie groepe verdeel. Hulle is versoek om, met inagneming van bogenoemde, 'n voorgelegde konsepkurrikuluminhoud (gebaseer op vroeëre insette) te bestudeer, te bespreek en voorstelle vir verandering en verbetering te maak. Die fokusgroepe is deur deputate gelei wat deurentyd betrokke was by die voorafgaande prosesse om die konsepkurrikuluminhoude saam te stel. Insette is aangeteken en terugvoer is gegee en bespreek deur die afgevaardigdes. Alle insette is oorweeg en konsensus is oor die finale kurrikuluminhoude bereik. 
Tabel 1: Die ontwikkelingsgang van die hele proses

\begin{tabular}{|l|}
\hline Verkennende \\
dataversameling \\
(situasie- \\
analise) in die \\
vorm van ge- \\
skrewe insette/ \\
kommentaar \\
van gemeentes \\
en mondelinge \\
insette verkry \\
van kategete by \\
opleidingsessies \\
Bevindings dui \\
aan wat proble- \\
maties is m.b.t. \\
bestaande \\
handleidings en \\
kurrikulum- \\
inhoude
\end{tabular}

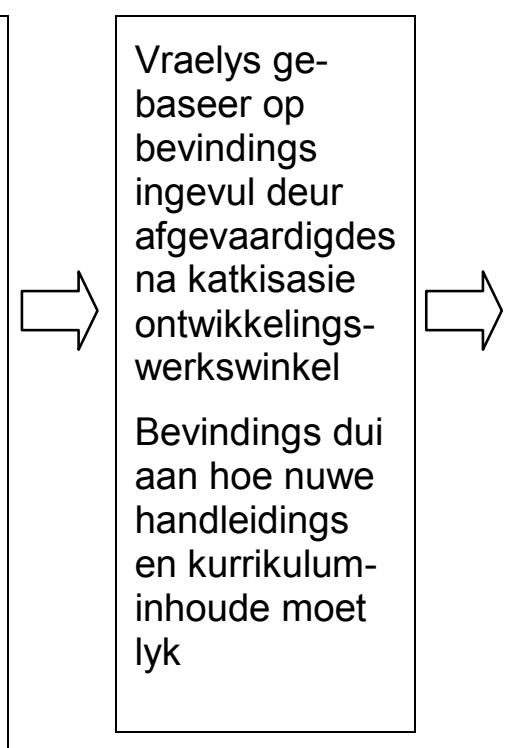

\begin{tabular}{|l|}
\hline Konsepkurriku- \\
luminhoude en \\
voorgestelde \\
formaat van \\
handleidings \\
voorberei en \\
gebaseer op \\
voorafgaande \\
bevindings \\
\hline
\end{tabular}

Werkswinkel met fokusgroepe om konsepkurrikuluminhoude en formaat te bespreek, te wysig, aan te pas en te verfyn

\section{4 'n Vergelyking tussen die ou en die nuwe kurrikulum- inhoude}

Die ouer kurrikuluminhoude wat in gebruik was, word ter inligting weergegee.

\section{Tabel 2: Die kurrikuluminhoude van 1999}

\begin{tabular}{|l|l|l|}
\hline Graad 1 & Graad 2 & Graad 3 \\
\hline Belydenis & Belydenis & Openbaringsgeskiedenis \\
\hline $\begin{array}{l}\text { Behoort aan Jesus } \\
\text { Christus }\end{array}$ & My doop & Tuin van Eden \\
\hline $\begin{array}{l}\text { Jesus Christus my } \\
\text { Verlosser }\end{array}$ & Christus se verdienste & Sondeval \\
\hline Dankie sê vir die Here & Goeie werke & Noag \\
\hline Openbaringsgeskiedenis & Openbaringsgeskiedenis & Verbond met Abram \\
\hline God maak alles & Jerigo & God is oral - Jakob \\
\hline Luister na die Here & $\begin{array}{l}\text { Die eer van die Here } \\
\text { kom eerste }\end{array}$ & $\begin{array}{l}\text { Ek moet vir ander tot } \\
\text { seën wees }\end{array}$ \\
\hline $\begin{array}{l}\text { Die Here weet of ons } \\
\text { Hom liefdevol dien }\end{array}$ & God is Koning & Jakob moet altyd vertrou \\
\hline Beloftes van die Here & Saul & Die tien plae \\
\hline Glo die beloftes & Dawid & Pasga \\
\hline
\end{tabular}




\begin{tabular}{|l|l|l|}
\hline Graad 1 & Graad 2 & Graad 3 \\
\hline $\begin{array}{l}\text { Dinge gebeur soos die } \\
\text { Here dit bepaal }\end{array}$ & Ons stryd teen die bose & $\begin{array}{l}\text { Ons is gebind aan die } \\
\text { Here }\end{array}$ \\
\hline $\begin{array}{l}\text { Satan kan die Here nie } \\
\text { keer nie }\end{array}$ & Gawes & $\begin{array}{l}\text { Aanbid die Here soos } \\
\text { Hy dit wil hê }\end{array}$ \\
\hline $\begin{array}{l}\text { Die Here aan ons kant } \\
\text { en ons aan sy kant }\end{array}$ & Die Here is God & Johannes die Doper \\
\hline Moses & 'n Dogtertjie vertel van \\
die Here & Geboorte van Jesus \\
\hline Die Rooi See & Gebede & Versoekings \\
\hline $\begin{array}{l}\text { Die Here se volk lewe uit } \\
\text { sy hand }\end{array}$ & God kan alles verander & $\begin{array}{l}\text { Die heerlikheid van } \\
\text { Jesus }\end{array}$ \\
\hline God word mens in Jesus & Die Here se goeie hand & Die opstanding \\
\hline Jesus is God & Hemelvaart & $\begin{array}{l}\text { Jesus bou op - die } \\
\text { duiwel breek af }\end{array}$ \\
\hline $\begin{array}{l}\text { Jesus seën die kinder- } \\
\text { tjies }\end{array}$ & Die Heilige Gees & $\begin{array}{l}\text { Bied weerstand teen die } \\
\text { duiwel }\end{array}$ \\
\hline Die kruisiging & Die eerste gemeente & $\begin{array}{l}\text { God se krag maak my } \\
\text { sterk }\end{array}$ \\
\hline Die opstanding & Wegbereiders & Belydenis \\
\hline Koninkryk & Saulus & Nagmaal \\
\hline God is Koning & Koninkryk & Sonde is ons eie skuld \\
\hline $\begin{array}{l}\text { Ons gesin moet God } \\
\text { liefhê }\end{array}$ & Stryd & $\begin{array}{l}\text { Ons kan nie self betaal } \\
\text { nie }\end{array}$ \\
\hline Kerk & Wese van die duiwel & Kerk \\
\hline $\begin{array}{l}\text { Die kerk moet die Here } \\
\text { dien }\end{array}$ & Dade van die duiwel & Kerk is 'n lig \\
\hline Die Here roep sy kerk & Kerk & Kerk soos lote \\
\hline $\begin{array}{l}\text { God maak 'n huisgesin } \\
\text { bymekaar }\end{array}$ & Sout van die aarde & $\begin{array}{l}\text { Die bruid wag op die } \\
\text { Bruidegom }\end{array}$ \\
\hline Die Here bou sy kerk & Kudde van God & \\
\hline
\end{tabular}

In die opstel van die nuwe kurrikuluminhoude is die volgende, gebaseer op die profiel van die katkisante in graad 1-3, as vertrekpunte geneem: Die laerskoolkind se lewe kan in twee fases verdeel word, naamlik 6-9 jaar en 9-12 jaar. Die ouderdom van kinders in graad 1-3 val binne die eerste kategorie. Hierdie fase word merendeels gekenmerk deur ' $n$ behoefte aan fantasie en sprokies. Kinders van hierdie ouderdom is fluks en voer opdragte met geesdrif 
uit, hoewel hulle aandag nie lank op een saak gefokus kan bly nie. Dit is vir hulle belangrik om met maats te speel. Die kind leer in hierdie stadium lees en skryf, en het 'n drang na kennis. Die kurrikulum moet met bogenoemde ontwikkelingsdinamiek rekening hou. Uit die ontwikkelingsdinamiek van kinders tussen 6-9 jaar oud blyk die behoefte aan verhale. Hierdie ouderdomsfase is dus ' $n$ unieke geleentheid om Bybelverhale op verskillende maniere met die kinders te medieer. In die samestelling van 'n nuwe kurrikuluminhoud is besluit om die eerste drie jare van "formele" kategese te gebruik om 'n liefde vir die Woord van die Here te kweek deur op die Bybelverhale te fokus.

Die volgende opvoedkundige riglyne is daarom vir die keuse van kurrikuluminhoude vasgestel:

- Klem word op die openbaringshistoriese feite geplaas, aangesien kinders makliker aan die hand van "stories" leer.

- Die handleidings moet daarop gemik wees om 'n liefde vir die Bybel by die kinders te kweek.

- Die doel van die Bybelverhale is om, na analogie van Psalm 78, die hoof, hart en hande van verbondskinders in die onderrig in ag te neem.

- In die loop van drie jaar word die Bybel tot en met die werk en verdienste van Jesus een maal deurgewerk.

- By elke jaargroep word die lewe van Jesus Christus weer herhaal, maar telkens vanuit 'n ander gedeelte en hoek. Die opvoedkundige beginsel, begin by die bekende en beweeg na die onbekende, is in hierdie opsig gevolg.

\section{Tabel 3: Die nuwe kurrikuluminhoude van 2009}

\begin{tabular}{|l|l|l|}
\hline Graad 1 & Graad 2 & Graad 3 \\
\hline Die Here skep & Die intog & Die profete waarsku \\
\hline Die eerste mense & Rut & Israel in ballingskap \\
\hline Sondeval & Eli, sy seuns en Samuel & Daniël en sy vriende \\
\hline Adam en Eva se kinders & Simson & Daniël en Nebukadnesar \\
\hline Die sondvloed & Saul & Daniël en Belsassar \\
\hline Toring van Babel & Dawid (1) & Ester \\
\hline Abraham & Dawid (2) & Esra en Nehemia \\
\hline
\end{tabular}




\begin{tabular}{|c|c|c|}
\hline Isak & Dawid en sy kinders & $\begin{array}{l}\text { Aankondiging van Jesus } \\
\text { se geboorte }\end{array}$ \\
\hline Jakob en Esau & Salomo & Geboorte van Jesus \\
\hline Josef & Agab en Isebel & Doop van Jesus \\
\hline Moses voor sy vlug & Elia (1) & Bruilof in Kana \\
\hline Moses na sy vlug & Elia (2) & Bad van Betesda \\
\hline $\begin{array}{l}\text { 'n Bos brand en die } \\
\text { Here gee werk }\end{array}$ & Elisa (1) & Storm op die see \\
\hline Luister Farao & Elisa (2) & Besetene van Gadara \\
\hline Die uittog & Jona & Dogtertjie van Jaïrus \\
\hline $\begin{array}{l}\text { Die Here sorg in die } \\
\text { woestyn }\end{array}$ & Hiskia & $\begin{array}{l}\text { Vermeerdering van } \\
\text { brood }\end{array}$ \\
\hline Jerigo & $\begin{array}{l}\text { Die Here hou sy beloftes } \\
\text { - die geboorte van Je- } \\
\text { sus }\end{array}$ & Jesus wandel op die see \\
\hline Bileam & Johannes die Doper & Wie is die belangrikste? \\
\hline Geboorte van Jesus & $\begin{array}{l}\text { Jesus se openbare op- } \\
\text { trede }\end{array}$ & $\begin{array}{l}\text { Die barmhartige Samari- } \\
\text { taan }\end{array}$ \\
\hline Saggeus & Jesus se gelykenisse (1) & Die Goeie Herder \\
\hline Dissipels in die storm & Jesus se gelykenisse (2) & Die vyeboom \\
\hline Kruisiging & Jesus se wonders (1) & Die verlore seun \\
\hline Opstanding & Jesus se wonders (2) & Talente \\
\hline Hemelvaart & Jesus se laaste week & Gevangeneming \\
\hline $\begin{array}{l}\text { Die Heilige Gees bly by } \\
\text { ons }\end{array}$ & Kruisgebeure & Kruisiging \\
\hline
\end{tabular}

\section{Die ontwerp van die handleidings}

Uit die proses wat hierbo bespreek is, het die katkisasiedeputate nou meer sekerheid gehad oor wat die kurrikuluminhoude moes behels waarvolgens die handleidings ontwikkel moes word. Met die ontwerp van die handleidings is die onderrig- en leerbenadering wat onder 5.1 bespreek is, in ag geneem. Handleidings moes dus nie net kurrikuluminhoude bevat nie, maar ook aan kategete leiding gee oor hoe om die lesse aan te bied en ook aandui watter leeraktiwiteite kon plaasvind. Die handleidings weerspieël daarom ook die onderrig- en leerbenadering en bevat die laaste drie elemente van kurrikulumontwerp, naamlik die keuse en klassifikasie van leerervarings, die beplanning en implementering van onderrig-leersituasies en die evaluering van katkisante. 


\subsection{Formaat van die handleidings}

Die handleiding vir graad 1-3 bestaan uit drie boekies per jaargroep, naamlik 'n kategeethandleiding, 'n handleiding vir ouers en kinders, asook 'n werkboek vir kinders.

Die volgende aspekte is in die handleidings ingesluit:

\subsubsection{Die kategeethandleiding}

- 'n Algemene inleiding met 'n profiel van die katkisante (kenmerke en vermoëns wat leer beïnvloed) en wenke oor die aanbieding van lesse (metodologiese riglyne)

- Lestema

- Lewenswaarheid (wat katkisante moet verwerf en uitleef)

- Skrifgedeelte

- Inleiding (hoe om die les te begin of die tema in te lui)

- Verkondiging (wat onderrig moet word en hoe dit gedoen kan word)

- Praktykmaking (hoe die lesinhoud met die werklike lewe van die katkisante in verband gebring kan word - hantering van lewensvraagstukke of uitdagings)

- Aktiwiteit (om die aktiewe deelname van katkisante te verseker)

- Inskerping (aktiwiteit om die lewenswaarheid in te skerp)

- Evaluering of assessering (vrae en/of aktiwiteite om te bepaal of kennis en begrip vasgelê is)

- Afsluiting

- Media wat gebruik kan word in aanbiedings

\subsubsection{Die ouer-en-kindhandleiding (gemik op voorbereiding)}

- 'n Praktiese taak oor die vorige les (om verworwe kennis en vaardighede in praktiese situasies toe te pas en in te oefen)

- Lestema

- Lewenswaarheid (wat katkisante moet verwerf en uitleef)

- Skrifgedeelte 
- Praktiese wenke hoe ouers kan help met voorbereiding

- Voorbereidingsaktiwiteit (om aktiewe leer aan te moedig en te verseker dat deeglike voorbereiding gedoen is

\subsubsection{Die katkisantwerkboek}

- Klasaktiwiteite (om aktiewe deelname van katkisante te verseker)

- Media wat gebruik kan word in die voltooiing van aktiwiteite

\subsection{Ontwerpproses van die handleidings}

Gereelde werkswinkels is gehou waar die lesmetodiek, lesplanne en spesifieke inhoude van die handleidings en individuele lesse bespreek en beplan is. Die uitgangspunt was die wete dat die handleidings verbondskinders moes lei om die Here te ken en om daardeur ook die vreugde van 'n verbondsverhouding te ervaar. Daarom is daar 'n sentrale godsopenbaring (tema) en lewenswaarheid vir elke les vasgestel.

Elke les is deur 'n bekwame en ervare onderwyseres geskryf. Die lesse is deur die deputate gekeur en daarna deur 'n teoloog dogmaties nagesien voordat dit na 'n professionele persoon gestuur is vir die grafika en bladuitleg. Hierna is dit gepubliseer en gemeentes kon dit aankoop. Die status van die handleiding is presies wat die begrip katkisasiehandleiding aandui, naamlik 'n gids by die Bybel. Geen boek kan immers die Bybel vervang nie.

\subsection{Samevatting van die beginsels waarop die kurrikulum- ontwerp geskoei is}

Dingemans (1991:74-76) het in sy besinning oor die antropologiese vertrekpunt in kategese gemeld dat drie komponente interafhanklik van mekaar is, naamlik die relasionele komponent, die historiese komponent en die verantwoordelikheid van die mens. In 'n holistiese beskouing van kategese is bogenoemde drie komponente op mekaar aangewese. Die belangrike rol van die geloofsgemeenskap (die kerk) word verder deur Dingemans (1991:136-137) benadruk. Geloofsbelewing is van 'n netwerk verhoudings (relasies) afhanklik, onder andere met die kerk van alle eeue. Geloofsbelewing kan nie van die tradisie (geskiedenis) geskei word nie en moet binne die ruimte van die plaaslike kerk as geloofsgemeenskap geskied. Die plaaslike kerk het, volgens Dingemans (1991:136), boonop die opdrag om verbondskinders deur middel van allerlei middels (soos onder andere kategese) met die geloofsfeite (vervat in die Bybel) in aanraking 
te bring. In die kurrikulumontwerp is gepoog om genoemde komponente met mekaar te versoen. Dit geskied deur die volgende:

- Die eise van 'n postmoderne samelewing as relasionele komponent is in ag geneem deur 'n lewenswaarheid en praktykmaking in elke les in te sluit.

- Die historiese agtergrond van kategese deur die eeue, ook binne die GKSA, is binne ' $n$ bepaalde teologiese tradisie in die kurrikulum (vgl. punt 2) vervat.

- Kategese binne die GKSA is as 'n belangrike middel gebruik om die geheimenisse van die geloofswaarhede aan verbondskinders te ontsluit.

Alles in ag geneem, is in die kurrikulumontwerp gepoog om op 'n bepaalde wyse 'n versoening tussen die onderskeie komponente te bewerkstellig. Hiermee word kinders binne die Gereformeerde tradisie toegerus om nie net deel van die geloofsgemeenskap te word nie, maar om ook in 'n postmoderne samelewing sinvol te kan funksioneer.

\section{Slot}

In hierdie artikel is gepoog om aan te toon dat die kerk deur die geskiedenis met die noodsaak van verbondsonderrig, ook bekend as kategese, gekonfronteer is. Hierdie uitdaging is aanvanklik met allerlei handboeke aangepak. Later het die fokus binne die GKSA na handleidings verskuif, omdat 'n handleiding verbondskinders begelei om die bybelse waarhede hulle eie te maak. In hierdie artikel is ' $n$ metode van kurrikuleringsontwerp bespreek wat in die ontwerp van die nuutste handleidings gebruik is en moontlik tot groot vrug in die toekoms deur gereformeerde kerke gebruik kan word. Kategese is doelgerigte onderrig en daarom vereis kurrikulumontwerp 'n spesifieke, deeglik-metodologiese beplanning en nadenke.

Verdere navorsing kan gedoen word om die effektiwiteit van die handleidings in die praktyk te bepaal en om die bybelse gronde vir kategese in diepte te ondersoek.

\section{Geraadpleegde bronne}

BIJLSMA, R. 1972. Kleine Catechetiek. Callenbach: Nijkerk.

BURGER, C. 1995. Gemeentes in transito: vernuwingsgeleenthede in 'n oorgangstyd. Kaapstad: Lux Verbi.

CALVIN, J. 1542 Le catechisme de l'Eglise de Genève: c'este à dire le formulaire d'instruire les enfans en la Chrestienté [The Catechism of the Church of Geneva]. Geneva: Meinema. 
CALVYN kyk Calvin

CARL, A.E. 1995. Teacher empowerment through curriculum development: theory into practice. Kenwyn: Juta.

CARL, A.E., VOLSCHENK, A., FRANKEN, T., EHLERS, R., KOTZE, K., LOUW, N. \& VAN DER MERWE, C. 1988. Kurrikulumontwikkeling in die primêre skool: 'n modulêre benadering. Kaapstad: Maskew Miller Longman.

CASTELLS, M. 2001. Information technology and global development. (In Muller, J., Cloete, N. \& Badat, S., eds. Challenges of globalization: South African debates with Manuel Castells. Kaapstad: Maskew Miller Longman. p. 1-21.)

CASTELLS, M. 2004. The information age: economy, society and culture. Vol. 2: The power of identity. Oxford: Blackwell.

CLANCEY, W.J. 1995. A tutorial on situated learning. (In Self, J., ed. Proceedings of the International Conference on Computers and Education, Taiwan. Charlottesville: AACE. p. 49-70.)

DE WET, C.J.H. \& COETZEE, J. 1943. Die beginsels, metode en geskiedenis van die kategetiese onderwys. Kaapstad: Nasionale Pers.

DINGEMANS, G.D.J. 1991. In de leerschool van het geloof: mathetiek en vakdidaktiek voor catechese en kerkelijk vormingswerk. Kampen: Kok.

FEUERSTEIN, R. 1980. Instrumental enrichment: intervention program for cognitive modifiability. Maryland: University Park Press.

FEUERSTEIN, R. 1990. The theory of structural modifiability. (In Presseisen, B., ed. Learning and thinking styles: classroom interaction. Washington: National Education Associations. p. 68-134.)

FEUERSTEIN, R. \& FEUERSTEIN, S. 1991. Mediated learning experience: a theoretical review. (In Feuerstein, R., Klien, P.S. \& Tannenbaum A.J., eds. Mediated learning experience (MLE): theoretical, psychosocial, and learning implications. London: Freund. p. 3-51.)

GEREFORMEERDE KERKE IN SUID-AFRIKA. 1976. Handelinge van die nege en dertigste sinode van die Gereformeerde Kerke in Suid-Afrika. Potchefstroom: Administratiewe Buro.

GEREFORMEERDE KERKE IN SUID-AFRIKA. 2006. Handelinge van die nege en veertigste sinode van die Gereformeerde Kerke in Suid-Afrika. Potchefstroom: Administratiewe Buro.

GKSA

kyk GEREFORMEERDE KERKE IN SUID-AFRIKA

GROBBELAAR, J. \& HENDRIKS, H.J. 2006. Wat gebeur globaal en plaaslik met kinders. Praktiese teologie in Suid-Afrika, 21(2):2-32.

HEYSTEK, N.P. 1987. Integrating the youth into the life and work of the church through education. In die Skriflig, 21(84):15-26.

JOOSTE, J.P. 1965. Studiegids vir kategetiek. Potchefstroom: Pro Rege.

LAVE, J. \& WENGER, E. 1991. Situated learning: legitimate peripheral participation. Cambridge: Cambridge University Press.

LE ROUX, G.P.V. \& ROSSOUW, P.J. 1992. Jeugbediening: verbondenheid of verwonding. In die Skriflig, 26(4):537-548.

LUTHER, M. 1529. Enchiridion: der kleine Catechismus für die gemeine Pfarrherrn und Prediger. Wittenberg: Würtzburg.

MARSHALL, C. \& ROSSMAN, G.D. 1999. Designing qualitative research. 3rd ed. New York: Longman. 
MCMILLAN, J.H. \& SCHUMACHER, S. 2006. Research in education: evidencebased enquiry. 6th ed. Boston: Pearson.

NEL, M. 1986. Jeug en evangelie. Pretoria: NG Kerkboekhandel.

NEL, M. 1987. Integrating youth into the full life and work of the church in worship. In die Skriflig, 21(84):3-14.

NEL, M. 2003. Youth ministry the challenge of individuation. Praktiese teologie in Suid-Afrika, 18(1):151-196.

PRINS, J.M.G. 2000. Die godsdienstige houdings van kerklike betrokke tieners. Praktiese teologie in Suid-Afrika, 15(1):82-100.

SPENER, P.J. 1675. Pia desideria. Frankfurt on Main: Zuurkamp.

SPOELSTRA, B. s.a. Algemene historiese kategetiek tot en met die sewentiende eeu. Potchefstroom: Teologiese Skool. (Ongepubliseerde klasdiktaat.)

STROMMEN, M.P. \& HARDEL, R.A. 2000. Passing on the faith: a radical new model for youth and family ministry. Minnesota: Angus \& Robertson.

SOUTH AFRICAN INSTITUTE FOR RACE RELATIONS. 2009. 3/10 children live with both parents: SAIRR report. SAIRR Fast Facts, 13 Jul.

STATSSA. 2005. Marriages and divorces 2002: statistical release P0307. Pretoria: Government Printer.

SWEET, L. 2007. Sal die kerk van die toekoms vandag oorleef? (In Joubert, S., Van der Watt, J., Sweet, I., Easum, B. \& Niemandt, N., reds. Die perfekte storm. Vereeniging: Christelike Uitgewersmaatskappy. p. 15-44.)

UNICEF. 2006. The state of the world's children: excluded and invisible. http://www.unicef.org/sowc06/index.php Date of access: 19 Des. 2011.

VAN DER MERWE, C.N. 2009. Korrels uit die kategese in die GKSA. Die Kerkblad, 36-37, Feb. (Feesuitgawe.)

VYGOTSKY, L.S. 1978. Mind in society. Cambridge: Harvard University Press.

VYGOTSKY, L.S. \& LURIA, A. 1993. Studies on the history of behavior. Ed. and trans. by V.I. Golod and J.E. Knox. Hillsdale: Erlbaum.

\section{Kernbegrippe:}

katkisasiehandleidings

katkisasiekurrikulum

\section{Key concepts:}

catechism curriculum

catechism guides 
